\title{
GROUSE FLYING CRAZY AND DRUMMING HIGH
}

DENNIS FAST, Box 151, Kleefeld, Manitoba, ROA OVO

I am writing in response to a rather interesting article on Ruffed Grouse "crazy flights" by Victor Friesen in the December, 1978, Blue Jay. As a result of our winter feeding program, we have had a lot of grouse activitiy in and around our backyard over the past 2 years. Unfortunately, i do not have so detailed a set of observations as Mr. Friesen, but I would like to make some general comments.

During the past 2 years, I know of at least seven grouse that have died as a result of smashing into our house, and another two that have lived to tell the tale. Of these nine incidents I have witnessed four. In most cases (six), the grouse hit windows; in at least two cases they hit the side of the house; and the other case was undetermined because we found the grouse dead near the house, but with no broken window in sight. In most of the cases that I observed (or saw the broken window evidence), the grouse hit the house at a height of about $2 \mathrm{~m}$.

In one instance that I witnessed, the grouse seemed to be in pursuit of others. As they approached the house, the leading grouse veered off into the woods and disappeared. Unfortunately, the pursuing bird did not react in time, and hit the side of the house at top speed. It died almost instantly.

At the time of the above incident a year ago, our house was painted white. Mr. Friesen speculates that grouse may mistake a white house for a dull sky. During the past year, however, we have redone our house in natural (slightly brown) cedar, and the grouse are still hitting it!

On 12 January, 1979, at 5:13 p.m. (my observation have improved after reading Mr. Friesen's article), I heard a dull thud and looked up just in time to see a grouse rebounding from the side of the house and beginning to flutter away again. It flew about $4-5 \mathrm{~m}$ before settling in the snow to rest. There it sat for about 5 minutes before walking another 5-6 $m$ into the woods. After several more minutes, it launched itself and disappeared above the trees.

This particular grouse, like the one a year ago, seems to have been attempting to manoeuvre between our house and the adjoining woodlot, a channel about $4 \mathrm{~m}$ wide. In the case of this year's grouse, however, it could hardly have mistaken our house for the sky; it seems rather to have misjudged its own ability to execute a banking curve in time to avoid the house!

My suspicions about the Ruffed Grouse's flying ability were intensified on 14 January, 1979. As the grouse moved in for their late afternoon feeding, I noticed several comical landings. In one case the grouse ended up half buried as it came to a "soft landing" by merely plunging into the snow. In another case, a bird flipped over and nearly tumbled head over heels as it attempted a similar landing in snow that was a bit harder. In any event, it would appear that the grouse has the kind of clumsy landing technique 
that would never get a would-be pilot his licence even if he lived to tell about it! And, as if that weren't bad enough, its flying style, too often, is not much better.

We live near Kleefeld, Manitoba, in a house that is nestled into mixed deciduous woods of aspen and oak. As a result, we see a fair number of Ruffed Grouse in and around our backyard. We encourage their winter presence by supplying them with crushed corn and peanut hearts, and it is not unusual for us to see 10 to 15 of these beautiful birds visiting our feeder at dawn and, especially, at dusk.

I'm sure that the winter feeding program encourages their yearround presence, and this enables us to witness the real treat of strutting and drumming males in full display.

A more unusual, but well-known behaviour, is that grouse will often drum in fall as well as in spring. However, it has been my observation that this fall drumming is usually less intense and not as persistent as the fever-pitched drumming of spring. It certainly is not an all-pervasive phenomenon, and I suspect that it may be the beginnings of the rites of spring for young males just beginning to "feel their oats" (or crushed corn, as the case may be)!

In any event, I have seen a male sitting on our feeding table in fall and drumming periodically over several days. This particular bird must have enjoyed the extra elevation $(1 \mathrm{~m})$ that the table provided for its drumming pronouncements.

This fall, however, our family witnessed what must surely be some sort of altitude record for a grouse's drumming perch. On 30 September, 1978, at about 8 a.m. I was awakened by the persistent drumming of a male Ruffed Grouse. Although I have heard this sound and witnessed the performance many times, it never fails to excite me and to arouse my curiosity. By this time our oldest boy, Stuart, age 11, had also heard it and made his way downstairs to check it out. In a few minutes came his excited shout, "It's on the roof!"

Needless to say, I was out there in a hurry. I could hardly believe my eyes, but on the very peak of the roof of our $1 \frac{1}{2}$ story house (8-9 m high) sat a male Ruffed Grouse. Over the course of the next 75 minutes I saw him drum repeatedly with almost the same intensity and regularity (every 3-5 minutes) as in the spring. The day was sunny and warm without a cloud in the sky - maybe Indian Summer makes fools of grouse!

I am wondering now whether this is an isolated case; or is there any other record of a grouse drumming in an unusual location or at such a remarkable altitude? If you know of any, I would be delighted to hear about it.

Editor's Note: Ruffed Grouse "have been known to drum during every month of the year and during every hour of the day and night". Drumming is most intensive from early March to early May but "there is also a short period in midautumn when this activity increases for a few weeks". "In the absence of appropriate, prostrate logs, mossy mounds or boulders; stone walls, rail fences, or similar objects are sometimes used for the stage". From: F. C. Edminster. 1947. The Ruffed Grouse. MacMillan, New York. 383 pp. 